\title{
Hubungan konsep diri dengan interaksi sosial siswa SMPN 253
} Jakarta

\author{
Adeliya Noviyanti ${ }^{1 *}$, Miskanik Miskanik ${ }^{2)}$, T. Sunarto ${ }^{3)}$ \\ 1,2,3) Universitas Indraprasta PGRI \\ *) adeliyanov@gmail.com
}

\author{
Article History: \\ Received: 03/08/2021; \\ Revised: 19/10/2021. \\ Accepted: 22/10/2021 \\ Published: 30/10/2021.
}

How to cite:

Noviyanti, A., Miskanik, M., \& Sunarto, T. (2021). Hubungan konsep diri dengan interaksi sosial siswa SMPN 253 Jakarta. Orien: Cakrawala Ilmiah Mahasiswa, 1(2), pp. 185-190. DOI: 10.30998/ocim.v1i2.4969

(c) (i) This is an open distributed under the Creative Commons 4.0 Attribution License, which permits unrestricted use, distribution, and reproduction in any medium, provided the original work is properly cited. (C) 2021, Noviyanti, Miskanik, \& Sunarto.

\begin{abstract}
Abstrak: siswa di sekolah diharapkan mampu menjalin interaksi sosial yang positif dan dinamis dengan seluruh warga sekolah. Kenyataanya masih terdapat siswa yang belum mampu berinteraksi sosial secara optimal. Konsep diri ditengarai berhubungan dengan keadaan ini. Penelitian ini bertujuan untuk mengetahui hubungan antara konsep diri dengan interaksi sosial siswa SMPN 253 Jakarta. Penelitian ini adalah penelitian kuantitatif dengan menggunakan metode korelasi. Data diperoleh melalui penyebaran kuesioner kepada siswa. Sampel dalam penelitian ini berjumlah 60 siswa dengan menggunakan teknik random sampling. Hasil penelitian mengungkapkan bahwa terdapat hubungan antara konsep diri dengan interaksi sosial siswa SMPN 253 Jakarta.
\end{abstract}

Kata Kunci: konsep diri, interaksi sosial

\begin{abstract}
: students in schools are expected to be able to establish positive and dynamic social interactions with all school members. In fact, there are still students who have not been able to interact socially optimally. Self-concept is suspected to be related to this situation. This study aims to determine the relationship between selfconcept and social interaction of students at SMPN 253 Jakarta. This research is quantitative research using correlation method. Data was obtained through distributing questionnaires to students. The sample in this study amounted to 60 students using random sampling technique. The results of the study reveal that there is a relationship between self-concept and social interaction of students at SMPN 253 Jakarta
\end{abstract}

Keywords: self-concept, social interaction

\section{Pendahuluan}

Manusia selain menjadi makhluk sosial juga merupakan makhluk hidup, manusia akan mengalami pertumbuhan perkembangan dalam dirinya seiring dengan bertambahnya usia. Pertumbuhan dan perkembangan yang terjadi dapat menyebabkan manusia mengalami perubahan pada dirinya. perubahan tersebut yaitu se[erti perubahan fisik, cara berpikir, perilaku dan lainnya.

Seseorang mampu menilai dirinya sendiri baik kekurangan dan kelebihannya. Pemahaman terhadap diri sendiri juga penting di dalam penilaian sosial dan perilaku sosial. Bagaimana kita memahami diri kita sendiri berpengaruh pada bagaimana kita memahami dan memperlakukan orang lain. Usaha seseorang dalam memahami serta mengerti dirinya sendiri menghasilkan konsep mengenai dirinya tersebut atau yang disebut sebagai konsep diri. Menurut Thalib (2010) konsep diri merupakan representasi dari diri yang mencakup identitas diri yakni 
karakteristik personal, pengalaman, peran dan status sosial. Konsep diri dapat membantu individu untuk menggambarkan pengetahuan individu tersebut untuk mengetahui dan mengenal dirinya. pada periode remaja, situasi psikologis dan fisiologis besar pengaruhnya terhadap perkembangan individu dalam membentuk pribadinya dibandingkan dengan priode sebelumnya. Agar potensi individu berkembang dengan optimal, individu perlu memahami dirinya. saah satu pemahaman dari siswa yang baik adalah siswa memiliki konsep diri yang baik, karena konsep diri merupakan suatu penilaian mengenai keadaan diri sendiri yang relatif sulit diubah menurut (Folastri \& Prasetyaningtias, 2017).

Berdasarkan fenomena yang sering terjadi mengenai konsep diri, diketahui terdapat siswa yang memiliki konsep diri rendah yaitu seperti hal nya siswa yang tidak mempunyai kepercayaan terhadap dirinya sendiri terutama dalam hal pelajaran yang sebenarnya ia mampu namun ia takut, siswa yang pendiam dan sulit untuk bergabung dengan teman lainnya serta merasa sulit untuk berkomunikasi dengan orang lain dan fenomena-fenomena atau permasalahan lainnya yang dialami oleh siswa yang belum memahami konsep diri.

Penilaian konsep diri dapat bersifat positif dan negatif. Seorang yang merasa dirinya diterima dilingkungan akan cenderung memiliki konsep diri positif, namun sebaliknya seseorang yang merasa dirinya ditolak dilingkungan akan cenderung memiliki konsep diri yang negatif. Konsep diri sangat berpengaruh dikehidupan, karena pada masa ini remaja akan masa krisis dimana remaja mulai berusaha untuk mencari identitas diri untuk menjadi orang dewasa sesuai dengan perkembangannya. Remaja dituntut untuk dapat menyesuaikan diri dengan lingkungan sosial yang lebih luas dan majemuk. Proses hubungan antar remaja tersebut berupa suatu proses dalam interaksi sosial yang terjadi dalam kehidupan sehari-hari. Siswa dalam pembentukan konsep dirinya dipengaruhi oleh lingkungan mereka berada. Banyak siswa yang mendefinisikan diri sendiri melalui perbandingan dengan orang lain. Disinilah peran interaksi sosial siswa dalam pembentukan konsep diri.

Menurut Jahia (2013) bahwa interaksi sosial merupakan salah satu syarat untuk pertumbuhan jiwa, apabila tidak terpenuhi akan menghambat perkembangan jiwa siswa. Salah satu perkembangan jiwa adalah perkembangan konsep dirinya. oleh sebab itu interaksi sosial penting bagi perkembangan diri siswa agar dapat berjalan dengan baik. Interaksi sosial merupakan suatu proses berhubungan sosial, yang dapat membantu individu untuk dapat mengenal diri serta dapat membantu individu untuk mengubah, mempengaruhi, serta memperbaiki kehidupan individu yang satu dengan yang lainnya. individu melakukan interaksi sosial dengan individu lainnya, tidak hanya dikarenakan individu sebagai makhluk sosial yang membutuhkan orang lain melainkan interaksi sosial merupakan salah satu kebutuhan dasar. Interaksi sosial merupakan kebutuhan setiap makhluk hidup, karena dengan berinteraksi manusia dapat bertukar pikiran dan pengetahuan menurut (Riansyah \& Wulandari, 2017).

Pada penelitian ini, penulis meneliti hubungan antara konsep diri siswa dengan interaksi sosial siswa disekolah atau dilingkungan, apakah terdapat hubungan terutama ketika sedang terjadi proses sosialisasi antara individu ataupun kelompok. Interaksi sosial dalam lingkungan akan membentuk konsep diri siswa. Pengalaman hasil interaksi sosial siswa akan memberikan pandangan baru terhadap diri siswa yang dapat memberikan konsep diri siswa. Pengalaman yang menyenangkan memberi kepuasan yang cenderung membangkitkan konsep diri yang positif begitu sebaliknya. Namun pembentukan konsep diri tidak sepenuhnya berjalan dengan baik karena adanya permasalahan dalam interaksi sosial siswa. Berdasarkan penjelasan tersebut, maka tujuan penelitian ini adalah untuk mengetahui hubungan antara konsep diri dengan interaksi sosial siswa SMPN 253 Jakarta. 


\section{Metode}

Metode penelitian yang digunakan dalam penelitian ini adalah metode penelitian kuantitatif dengan jenis penelitian yaitu korelasi. Menurut Arikunto (2010) bahwa penelitian korelasi merupakan penelitian yang dimaksud untuk mengetahui ada tidaknya hubungan antara dua atau beberapa variabel. Pada penelitian ini akan dicari hubungan antara kedua variabel yaitu variabel konsep diri $(X)$ dan variabel interaksi sosial $(Y)$. Penelitian ini dilakukan di SMPN 253 Jakarta dengan sampel dalam penelitian ini sebesar 60 orang siswa menggunakan teknik random sampling. Waktu penelitian yaitu pada bulan mei 2021 sampai dengan bulan juni 2021. Metode pengumpulan data yang digunakan pada penelitian ini yaitu kuesioner. Analisis data dalam penelitian ini menggunakan program SPSS versi 23.0.

\section{Hasil dan Diskusi}

Berdasarkan dari hasil penyebaran mengenai variabel konsep diri dan interaksi sosial terhadap 60 siswa, diperoleh hasil gambaran umum pada tabel berikut:

Tabel 1. Gambaran Umum Konsep Diri Siswa SMPN 253 Jakarta

\begin{tabular}{cccc}
\hline Skor Interval & Kriteria & Frekuensi \\
\hline $80-95$ & Sangat Tinggi & 8 \\
$65-79$ & Tinggi & 35 \\
$50-64$ & Sedang & 17 \\
\hline & Jumlah & & $\mathbf{6 0}$ \\
\hline
\end{tabular}

Sumber: Diolah dari data hasil penelitian, 2021

Berdasarkan tabel 1 dapat diketahui bahwa yang termasuk dalam kriteria sangat tinggi dengan skor interval 80-95 terdapat delapan siswa, kriteria tinggi dengan skor interval 65-79 terdapat tiga siswa dan kriteria sedang dengan skor interval 50-64 terdapat 17 siswa. Total keseluruhan 60 siswa. Untuk variabel interaksi sosial disajikan pada tabel 2 berikut.

Tabel 2. Gambaran umum Interaksi Sosial SMPN 253 Jakarta

\begin{tabular}{cccc}
\hline Skor Interval & Kriteria & Frekuensi \\
\hline $90-105$ & Sangat Tinggi & 19 \\
$73-89$ & Tinggi & 39 \\
$56-72$ & Sedang & 2 \\
\hline & Jumlah & & $\mathbf{6 0}$ \\
\hline
\end{tabular}

Sumber: Diolah dari data hasil penelitian, 2021

Bedasarkan tabel 2 dapat diketahui bahwa yang termasuk dalam kriteria sangat tinggi dengan skor interval 90-105 terdapat 19 siswa, kriteria tinggi dengan skor interval 73-89 terdapat 39 siswa dan kriteria sedang skor interval 56-72 terdapat dua siswa. Total keseluruhan siswa yaitu 60 siswa. Secara umum gambaran perolehan data konsep diri dan interaksi sosial siswa disajikan pada tabel 3 berikut.

Tabel 3. Deskriptif Statistik

\begin{tabular}{cccccc}
\hline & $N$ & Minimum & Maximum & Mean & Std. Deviation \\
\hline Konsep Diri & 60 & 58 & 90 & 71.08 & 7.525 \\
Interaksi Sosial & 60 & 61 & 99 & 85.47 & 7.233 \\
Valid N (listwise) & 60 & & & & \\
\hline
\end{tabular}


Berdasarkan tabel 3 menunjukan bahwa $\mathrm{N}$ atau jumlah data setiap variabel yang valid berjumlah 60. Pada variabel konsep diri $(X)$, diketahui nilai minimum sebesar 58, nilai maksimum sebesar 90, nilai mean sebesar 71.08 dan nilai standar deviasi sebesar 7.525, yang artinya pada tabel 3 terlihat nilai mean lebih besar dari nilai standar deviasi. Pada variabel interaksi sosial (Y), diketahui nilai minimum sebesar 61, nilai maksimum sebesar 99, nilai mean sebesar 85.47 dan nilai standard deviasi sebesar 7.233 yang artinya pada tabel 3 terlihat nilai mean lebih besar dari nilai standar deviasi.

Berdasarkan tabel tabulasi silang konsep diri dan interaksi sosial diperoleh bahwa konsep diri siswa yang masuk dalam kategori sangat tinggi sebanyak delapan siswa yang di dalamnya terdapat enam siswa memiliki interaksi sosial tinggi dan dua siswa memiliki interaksi sosial sangat tinggi. Untuk konsep diri siswa yang masuk ke dalam kategori sedang ada sebanyak 17 siswa yang terdapat di dalamya 10 siswa memiliki interaksi sosial tinggi, tujuh siswa memiliki interaksi sosial sangat tinggi dan untuk konsep diri siswa yang masuk ke dalam kategori tinggi ada sebanyak 35 siswa yang terdapat di dalamnya 23 siswa memiliki interaksi sosial tinggi, 10 siswa memiliki interaksi sosial sangat tinggi dan dua siswa memiliki interaksi sosial sedang.

Pada penelitian ini penulis menggunakan uji normalitas yang bermaksud untuk menguji apakah data yang disajikan untuk dianalisis lebih lanjut berdistribusi normal atau tidak. Untuk mengujinya digunakan uji Kolmogorov Smirnov. Pengambilan keputusan untuk menentukan apakah data yang diuji berdistribusi normal atau tidak adalah dengen menentukan nilai signifikannya jika signifikan > 0,05 maka berdistribusi normal dan sebaliknya jika nilai signifikan $<0,05$ maka variabel tidak berdistribusi normal. Berdasarkan hasil uji normalitas diketahui nilai signifikan 0,200>0,05. Maka dapat disimpulkan bahwa nilai residual berdistribusi normal.

Pada penelitian ini juga penulis menggunakan uji linearitas yang bertujuan untuk mengetahui apakah dua variabel mempunyai hubungan yang linear atau tidak secara signifikan. uji linearitas dilakukan dengan pengujian pada SPSS versi 23.0 for windows dengan menggunakan test for linearity pada taraf signifikan 0,05. Dua variabel dikatakan mempunyai hubungan yang linear bila signifikan $>0,05$. Berdasarkan pada hasil uji linearitas diperoleh nilai sig. deviation from linearity $0.133>0.05$, maka dapat disimpulkan bahwa terdapat hubungan yang linear antara variabel konsep diri dengan variabel interaksi sosial.

Untuk memastikan dan mengetahui ada tidaknya hubungan antara konsep diri dengan interaksi sosial, maka dilakukan uji hipotesis menggunakan korelasi product moment dengan program SPSS versi 23.0. Adapun hasil pengujian di sajikan dalam tabel berikut

Tabel 4. Hasil perhitungan korelasi

\begin{tabular}{llcc}
\hline & & Konsep Diri & Interaksi Sosial \\
\hline Konsep Diri & Pearson Correlation & 1 & .463 \\
& Sig. (2-tailed) & & .000 \\
& $N$ & 60 & 60 \\
Interaksi Sosial & Pearson Correlation & .463 & 1 \\
& Sig. (2-tailed) & .000 & 60 \\
& $N$ & 60 & \\
\hline
\end{tabular}

Sumber: Output SPSS

Pada tabel 4 diketahui nilai korelasi sebesar 0,463 dengan kriteria penafsiran jika rhitung > rtabel berarti terdapat hubungan yang positif antara variabel konsep diri dengan variabel interaksi sosial, dan jika rhitung $<$ rtabel maka tidak ada hubungan antara kedua variabel. Diketahui dari tabel product moment untuk $\mathrm{n}=60$ pada taraf $5 \%$ yaitu rabel $=0,254$ dan rhitung $=0,463$. Berdasarkan hasil 
tersebut dapat disimpulkan bahwa terdapat hubungan positif antara konsep diri dengan interaksi sosial siswa SMPN 253 Jakarta yang artinya semakin tinggi konsep diri yang dimiliki siswa semakin tinggi pula interaksi sosial siswa terhadap lingkungan.

Berdasarkan dari nilai rhitung sebesar $=0,463$ yang berarti nilai tersebut menunjukan bahwa variabel konsep diri dengan interaksi sosial memiliki hubungan dalam kategori sedang, dengan melihat hasil perhitungan dengan menggunakan interprestasi koefisien korelasi. Serta kategori sedang dalam penelitian ini berarti cukup baik. Hal ini dikarenakan konsep diri siswa berkembang ke arah yang lebih ideal serta lingkungan sosial siswa yang semakin luas yang mengharuskan siswa melakukan interaksi agar diterima dalam lingkungannya.

\section{Simpulan}

Berdasarkan hasil penelitian mengungkapkan bahwa terdapat hubungan antara konsep diri dengan interaksi sosial siswa SMPN 253 Jakarta yang berada pada kategori sedang. Hal ini berarti bahwa siswa sudah memiliki konsep diri yang baik serta siswa dapat berinteraksi sosial dengan baik di lingkungan terutama lingkungan sekolah. Siswa dapat meningkatkan kualitas komunikasinya serta kepercayaan terhadap dirinya sendiri. Sehingga siswa dapat mengembangkan dirinya menjadi lebih baik kedepannya.

\section{Ucapan Terima Kasih}

Penulis mengucapkan terimakasih kepada orang tua, keluarga, bapak dan ibu pembimbing skripsi, teman-teman, guru BK, siswa-siswi SMPN 253 Jakarta dan lainnya yang telah mendukung terwujudnya artikel ini.

\section{Daftar Rujukan}

Ambarwati, Dian. (2016). “Hubungan Konsep Diri dengan Interaksi Sosial Siswa Kelas IV SD Negeri Se-kecamatan Mergangsang". (Skripsi). Sekolah Sarjana. Universitas Negeri Yogyakarta.

Anwar, F. (2016). Hubungan antara Konsep Diri dengan Interaksi Sosial pada Siswa Kelas IV Sekolah Dasar Negeri 3 Yogyakarta. Jurnal Psikologi. 13(25)

Arum, Retna Anindita dan Hermien Laksmiwati. (2015). Hubungan antara Konsep Diri dan Interaksi Sosial Teman Sebaya dengan Kemandirian Belajar pada Siswa Kelas X SMA Negeri 12 Surabaya. Jurnal Penelitian Psikologi. 3(2).

Folastri, Sisca dan Wahyu Eka Prasetyaningtyas. (2017). Gambaran Konsep Diri Siswa di Sekolah Menengah Kejuruan Sumbangsih Jakarta Selatan. Terapeutik: Jurnal bimbingan dan konseling. 1(1), hlm 33-40.

Miraningsih, Wahyu. (2013). “Hubungan antara Interaksi Sosial dan Konsep Diri dengan perilaku Reproduksi Sehat pada Siswa Kelas XI di Madrasah Aliyah Negeri (MAN) Purworejo". (Skripsi). Sekolah Sarjana, Universitas Negeri Semarang.

Riansyah, Hafit dan Wulandari. (2017). Layanan Bimbingan Kelompok dalam Meningkatkan Interaksi Sosial Siswa. Teraputik: jurnal bmbingan dan konseling. 1(1) hlm 47-52.

Sarwono, Sarlito W dan Eko A. Meinarno. (2015). Psikologi Sosial. Jakarta: Salemba Humanika. 
190 Hubungan konsep diri dengan interaksi sosial siswa SMPN 253 Jakarta

Sugiyono. (2017). Metode Penelitian, Kuantitatif, Kualitatif dan R\&D. Cetakan 26. Bandung: Alfabeta.

\section{Competing interests:}

The authors declare that they have no significant competing financial, professional or personal interests that might have influenced the performance or presentation of the work described in this manuscript. 